\title{
EDUCATION AND TRAINING IN RADIATION PROTECTION IN KOREA: CURRENT STATUS AND IMPROVEMENTS
}

\author{
MIYEON SON, HYUNKEE KIM", YOUNGMI NAM, JONGSOO NAM, and KI-BOG LEE \\ Nuclear Training and Education Center \\ Korea Atomic Energy Research Institute, Daejeon, 305-353, Korea \\ *Corresponding author. E-mail : hkkim0@kaeri.re.kr \\ Received November 08, 2011 \\ Accepted for Publication February 08, 2012
}

\begin{abstract}
Radiation and its various industrial applications have been growing at approximately 10 percent per year for the past decade in Korea. As a result, the importance of the Education and Training (E\&T) in radiation protection is of upmost importance. This paper is intended to investigate the present status of the E\&T on radiation protection and safety in Korea and to draw up the improvements of the E\&T courses required for building the national radiation safety infrastructure. For these purposes, the E\&T data from the six major domestic organizations providing radiation protection training courses were investigated and analyzed. Each of the organizations is offering several kinds of E\&T courses based on their own specific functions. These organizations have administrative facilities equipped with the latest technology for E\&T in radiation protection. The E\&T courses mainly cover the training courses for radiation workers, radiological emergency staff, license applicants, license holders, and regulatory staff. In 2010, a total of 58 E\&T courses were carried out across six organizations. The conclusions make a number of observations highlighting challenges such as: establishing a formal feedback mechanism, introducing more practical training sessions, developing training courses tailored to the job categories and target audiences, and designing education and training courses in radiation protection that comply with current obligations as well as future requirements.
\end{abstract}

KEYWORDS : Education and Training, Radiation Protection, Radiation Safety, Radiation Training Program, Training Course

\section{INTRODUCTION}

Radiation and its application industry in Korea have been steadily growing about 10 percent every year in the last decade [1,2]. In Korea, industrial applications for radiation have been growing at approximately $10 \%$ per year for the past decade.

Currently, there are more than 4,000 organizations that use radiaoactive isotopes in varied fields such as medicine, industry, research, and education [1]. In addition, growing energy demands will require that a new nuclear power plant be commissioned every year for the next decade. In particular, the Fukushima nuclear accident that occurred in March 2011 brought to the forefront the need to address the growing demand for increased accountability with regards to nuclear power plant safety and training. Education and training are key to the sustainability of the nuclear industry in Korea, and this is truer today than at any point in the past. Therefore, it is of upmost importance to establish the appropriate conditions for the recognition of nuclear professional qualifications, to chart knowledge related to occupations in the nuclear field, and reinforce the teaching of essential scientific skills required for the safe management of the rapidly expanding nuclear sector.
The importance of education and training (hereafter referred to as "E\&T") in radiation protection is emphasized with an increase in the number of uses for the application of radioactive isotopes and an enhancement in precautionary measures required to address the safe handling, storage, and use of radioactive materials. An effective radiation protection training program is essential to safeguarding the health, safety, and security of workers, and the environment, as well as the development of the domestic nuclear and radiation industry. This work is intended to investigate the present status of the E\&T related to radiation safety in Korea and to suggest improvements to ensure that appropriately educated and trained professionals are in place to meet the criteria required for building a safe nuclear infrastructure.

\section{MATERIALS AND METHODS}

There are several organizations that carry out E\&T in radiation safety and protection in Korea. They have been providing various kinds of $E \& T$ courses to radiation related personnel. In order to understand the present status of the E\&T related to radiation safety in Korea, the E\&T data from the six major organizations were investigated: 
Table 1. Information on Education and Training Organizations

\begin{tabular}{|c|c|c|c|c|c|c|}
\hline \multirow{2}{*}{ Organizations } & \multirow[b]{2}{*}{ Departments } & \multirow[b]{2}{*}{ Training materials } & \multicolumn{3}{|c|}{ Available training methods } & \multirow{2}{*}{ Feedback process ${ }^{*}$} \\
\hline & & & $\begin{array}{l}\text { Classroom } \\
\text { instruction }\end{array}$ & Practical exercise & Distance learning & \\
\hline KAERI & 2 & $\mathrm{O}$ & $\mathrm{O}$ & $\mathrm{O}$ & $\mathrm{O}$ & $\mathrm{O}$ \\
\hline KINS & 1 & $\mathrm{O}$ & $\mathrm{O}$ & $\mathrm{O}$ & $\mathrm{O}$ & $\mathrm{O}$ \\
\hline KIRAMS & 1 & $\mathrm{O}$ & $\mathrm{O}$ & $\mathrm{O}$ & $\mathrm{O}$ & $\mathrm{O}$ \\
\hline KRIA & 1 & $\mathrm{O}$ & $\mathrm{O}$ & N/A & $\mathrm{O}$ & $\mathrm{O}$ \\
\hline KHNP & 4 & $\mathrm{O}$ & $\mathrm{O}$ & $\mathrm{O}$ & $\mathrm{O}$ & $\mathrm{O}$ \\
\hline KANDT & 1 & $\mathrm{O}$ & $\mathrm{O}$ & N/A & N/A & $\mathrm{O}$ \\
\hline
\end{tabular}

*All training organizations have its own internal procedures to get feedback from its training implemented. They are using their own written questionnaire to get feedback from trainees.

$\mathrm{KAERI}^{1}, \mathrm{KINS}^{2}{ }^{2} \mathrm{KRIA}^{3}, \mathrm{KIRAMS}^{4}, \mathrm{KHNP}^{5}$, and $\mathrm{KANDT}^{6}$. The details collected from each of the organizations include the E\&T courses, applicable training methods, training materials, number of participants, facilities, equipment, assessment for trainees, feedback procedures for the E\&T courses, etc.

Furthermore, specific topics covered in the training program were reviewed ascertain whether or not the appropriate knowledge and skills were conveyed to the participants. Considering that the practical exercises available to work field is one of the key issues in the E\&T, training courses that include practical exercises among the E\&T courses offered by each organization were identified. It allowed us to confirm that each of the E\&T courses covered both the theoretical and practical aspects of radiation protection and safety.

\section{RESULTS AND DISCUSSION}

\subsection{Education and Training Organizations}

As shown in Table 1, each organization has at least 1-4 departments offering E\&T programs depending on its specific function. All of them have developed their own training materials and have been utilizing them in the training courses. It is shown that distance learning is available for every organization. There were disparities in the facilities and equipment that each organization maintains. For KAERI, KINS, KIRAMS and KHNP, they

\footnotetext{
${ }^{1}$ Korea Atomic Energy Research Institute

${ }^{2}$ Korea Institute of Nuclear Safety

${ }^{3}$ Korea Radioisotope Association

${ }^{4}$ Korea Institute of Radiological and Medical Sciences

${ }^{5}$ Korea Hydro and Nuclear Power Co., LTD

${ }^{6}$ Korea Association for Non-Destructive Testing
}

have many different kinds of facilities and equipment from high performance devices to surveymeters: gamma spectrometry system, alpha spectrometry laboratory, gross alpha and beta activity measurement system, liquid scintillation counter physical and biological dosimetry laboratory, internal dose assessment laboratory, nondestructive testing system, various types of surveymeters and counters, classrooms, cyber studio for e-learning, etc. On the other hand, KRIA and KANDT are equipped with basic facilities and equipment for E\&T such as classrooms and several surveymeters and counters. These organizations are trying to make up for their shortfalls by establishing ties with universities, the government and other institutions.

\subsection{Education and Training Programs in Radiation Protection}

The major goal of E\&T in radiation protection is to provide essential knowledge and skills to any person who is occupationally exposed to radiation or who may be exposed in the course of work [3]. As shown tables 2 and 3 , many types of E\&T courses are provided by the six organizations observed.

In 2010, a total of $58 \mathrm{E} \& \mathrm{~T}$ courses were conducted in six organizations, and 19,206 participants completed the required courses. The trainees were assessed through written or practical examinations at the completion of the entire training courses. Every organization issued certificates to the trainees who completed their training courses.

Although all organizations are using their own written questionnaires to get feedback from trainees, a systematic procedure needs to be developed to improve the current course offerings. It is also found that there is no evaluation mechanism to validate the effectiveness of their E\&T courses, and to determine whether the program should be modified or improved.

Table 3 summarizes the objectives of each E\&T course and organizations executing it according to the objects to 
Table 2. Education and Training Carried out by Six Organizations in 2010

\begin{tabular}{c|c|c|c|c}
\hline Organizations & E\&T courses & Participants & Assessment methods & Certificate \\
\hline KAERI & 14 & 1,569 & Written & Yes \\
\hline KINS & 14 & 1,096 & Written & Yritten \\
\hline KIRAMS & 2 & 250 & Written & Yes \\
\hline KRIA & 9 & 9,996 & Written, Practical & Yes \\
\hline KHNP & 16 & 4,679 & Written & Yes \\
\hline \hline
\end{tabular}

Table 3. Education and Training Programs in Radiation Protection According to the Target Audiences

\begin{tabular}{|c|c|c|c|c|}
\hline Classification & Objectives & Target & $\begin{array}{l}\text { Number of } \\
\text { trainees }\end{array}$ & $\begin{array}{l}\text { Organizations offering } \\
\text { training courses }\end{array}$ \\
\hline $\begin{array}{l}\text { Training courses for } \\
\text { radiation workers } \\
\text { (initial \& refresher) }\end{array}$ & $\begin{array}{l}\text { To understand ways on safe handling of } \\
\text { radiation and radiation protection }\end{array}$ & Radiation workers & 14,551 & $\begin{array}{l}\text { KAERI, KINS, KRIA, } \\
\text { KHNP, KANDT }\end{array}$ \\
\hline $\begin{array}{l}\text { Refresher training courses } \\
\text { for license holders }\end{array}$ & $\begin{array}{c}\text { To improve competence in radiation } \\
\text { safety management }\end{array}$ & License holders & 560 & KAERI, KRIA \\
\hline $\begin{array}{l}\text { Radiological emergency } \\
\text { training courses }\end{array}$ & $\begin{array}{c}\text { To build emergency response capabilities } \\
\text { in radiation accident }\end{array}$ & $\begin{array}{c}\text { Radiological } \\
\text { emergency staff }\end{array}$ & 1,664 & $\begin{array}{l}\text { KAERI, KINS, } \\
\text { KIRAMS, KRIA, KHNP }\end{array}$ \\
\hline $\begin{array}{l}\text { Training courses for } \\
\text { license applicants }\end{array}$ & $\begin{array}{l}\text { To acquire basic knowledge and } \\
\text { techniques for handling radiation and } \\
\text { radioisotopes }\end{array}$ & License applicants & 631 & KAERI, KRIA \\
\hline $\begin{array}{l}\text { Training courses for } \\
\text { regulatory staff } \\
\text { (initial \& refresher) }\end{array}$ & $\begin{array}{l}\text { To acquire knowledge of regulatory } \\
\text { inspection for nuclear and radiation } \\
\text { facilities }\end{array}$ & Regulatory staff & 333 & KINS \\
\hline $\begin{array}{l}\text { Specialized training } \\
\text { courses ( } 10 \text { courses) }\end{array}$ & $\begin{array}{l}\text { To build expertise of radiation safety } \\
\text { management }\end{array}$ & $\begin{array}{l}\text { Radiation } \\
\text { management staff }\end{array}$ & 244 & $\begin{array}{l}\text { KAERI, KINS, KRIA, } \\
\text { KHNP }\end{array}$ \\
\hline $\begin{array}{l}\text { Training courses for } \\
\text { training the trainer }\end{array}$ & $\begin{array}{l}\text { To understand design, development, } \\
\text { implementation and evaluation of } \\
\text { training courses }\end{array}$ & $\begin{array}{l}\text { Radiation safety } \\
\text { experts }\end{array}$ & 70 & KINS, KRIA \\
\hline $\begin{array}{l}\text { Other courses } \\
(19 \text { courses })\end{array}$ & $\begin{array}{l}\text { To provide basic knowledge for } \\
\text { nuclear/radiation and its safe use }\end{array}$ & $\begin{array}{l}\text { Nuclear or } \\
\text { radiation staff }\end{array}$ & 1,153 & $\begin{array}{l}\text { KAERI, KINS, KRIA, } \\
\text { KHNP }\end{array}$ \\
\hline
\end{tabular}


be trained. KAERI, KINS, and KHNP provide training courses for their radiation workers and radiological emergency staff as well as specialized courses that cover specific subjects: analysis of gamma radionuclides, internal dose assessment, practical use of radiation safe codes, radiation measurement, etc. KINS as a regulatory body is operating training courses targeted at its regulatory staff. KRIA offers training courses for radiation workers, relevant license holders, and radiological emergency staff, as well as several specialized courses. It trains around 10,000 persons every year who work in the radiation and radioisotopes industries and educational institutions. KRIA and KAERI are designated as E\&T institutions carrying out qualification courses of applicants for licenses regarding safe handling of radioactive isotopes by the Ministry of Education, Science and Technology. KIRAMS is specialized in medical applications of radiation and radioisotopes. It mainly carries out training courses on medical services in a radiation emergency for medical personnel, fire fighters, and police officers. KANDT provides training courses for nondestructive testing workers.

Table 3 also shows the number of trainees who attended E\&T courses according to the target audiences in 2010. As easily expected, most of the trainees are radiation workers who participated in initial and refresher trainings courses for their jobs (14,551 people). The second largest group was radiological emergency staff who attended radiological emergency training courses (1,664 people). These two training courses are legal education and training set by the Atomic Energy Act and the Act on Physical Protection and Radiological Emergency, respectively.

\subsection{Improvements of Education and Training in Radiation Protection}

Assessments are necessary to verify whether trainees have mastered the training objectives and acquired the competence needed to perform their jobs safely. It is advisable that trainee progress be assessed at regular intervals, such as after each lesson or exercise, and again at the completion of the entire training courses. As mentioned above, training courses need to be dynamic by incorporating a "feedback mechanism" that facilitates response to the results of program evaluations thus leading to continuous improvement of the programs.

Table 4 shows training courses in which practical training is reflected in the course, and the fraction of practical training in each course. The fraction of training courses including practical training is less than $36 \%$ for all institutions, except for KIRAMS. In the majority of cases, however, practical training is only covered in a limited number of courses, such as courses for license applicants and radiological emergency staff, and in specialized courses and not in courses for radiation workers which make up the majority of trainees in Korea. It was also found that the fraction of practical exercises were not yet sufficient in each of the courses, even though it contained practical training. It goes without saying that practical exercises are one of the most effective methods for workers to master techniques required in their workplace. In order to ensure more effective and practical courses, various exercise sessions based on solid domestic E\&T infrastructure should be developed and incorporated in the existing E\&T courses.

In addition, the content and depth of radiation protection training need to correspond to specific occupations (e.g. industry, medical), types of source (e.g. sealed, unsealed), and individuals to be trained. For instance, the contents of training courses for radiation workers usually consist of general knowledge applicable to almost all radiation workers. Also, in training courses for license holders, same contents are given to the trainees regardless of the types of license they hold: licenses for supervisors of radiation handling, special licenses for radioisotope handling, and general licenses for radioisotope handling. A training program tailored to individual jobs and tasks will assure that participants are capable to perform their jobs in a safer manner and effective manner.

As stated above, each organization provides various kinds of E\&T courses, from very technical courses for a narrow target audience, to generalized courses. However, they do not run general courses for radiation protection staff who are actually in charge of the radiation safety management of an organization, although there are some short specialized courses handling this specific topic. The training of a radiation protection staff is likely to cover all practical radiation protection and safety aspects and skills associated with specific work tasks: the basic principles of radiation protection and source safety, the role and duties of the radiation protection staff, the supervision of work with radiation and compliance with specified regulations and procedures, the recognition of potentially unsafe situations, etc.

\section{CONCLUSIONS}

With the growth of Korea's nuclear and radiation industry each year, various E\&T programs in radiation protection and safety have been offered by several organizations. Each of them has administrative structures for $\mathrm{E} \& \mathrm{~T}$ and are equipped with a good infrastructure in terms of facilities or equipment despite the differences. The current E\&T programs mainly cover training courses for radiation workers, radiological emergency staff, license applicants, license holders, and regulatory staff. In 2010, a total of $58 \mathrm{E} \& \mathrm{~T}$ courses were held across six organizations. All of these training courses included assessments for the trainees, and certificates were issued to each of the individuals who completed their training course.

The areas for improvement were identified from an analysis present status of E\&T in radiation protection. These are listed below: 
Table 4. E\&T Courses Including Practical Training and Their Fraction in Each Course

\begin{tabular}{|c|c|c|c|}
\hline \multirow{2}{*}{ Organizations } & \multirow{2}{*}{$\begin{array}{c}\text { Percentage of courses } \\
\text { including practical training }(\%)\end{array}$} & \multicolumn{2}{|c|}{ Percentage of practical training in each course } \\
\hline & & Courses & $\%$ \\
\hline \multirow{5}{*}{ KAERI } & \multirow{5}{*}{36} & A & 46 \\
\hline & & $\mathrm{B}$ & 22 \\
\hline & & $\mathrm{C}$ & 24 \\
\hline & & $\mathrm{D}$ & 81 \\
\hline & & $\mathrm{E}$ & 21 \\
\hline \multirow{3}{*}{ KINS } & \multirow{3}{*}{21} & $\mathrm{~F}$ & 11 \\
\hline & & G & 40 \\
\hline & & $\mathrm{H}$ & 100 \\
\hline \multirow{2}{*}{ KIRAMS } & \multirow{2}{*}{100} & I & 38 \\
\hline & & $\mathrm{J}$ & 38 \\
\hline \multirow{5}{*}{ KHNP } & \multirow{5}{*}{31} & $\mathrm{~K}$ & 2 \\
\hline & & $\mathrm{L}$ & 8 \\
\hline & & M & 8 \\
\hline & & $\mathrm{N}$ & 20 \\
\hline & & $\mathrm{O}$ & 8 \\
\hline KRIA & 11 & $\mathrm{P}$ & 15 \\
\hline
\end{tabular}

- establish a formal feedback mechanism to measure the effectiveness of the training courses;

- introduce more practical training sessions to reinforce theoretical information and to master skills required on specific tasks;

- develop training courses tailored to the job categories and target audiences- develop a general training course for radiation protection staff

It is also highly recommended that the process for developing and maintaining radiation protection E\&T courses needs to be more systematic by considering the requirements and methods given in the International Basic Safety Standard[4] and related Safety Guides[3,5]. Such efforts would improve the effectiveness of current radiation protection training courses.

\section{REFERENCES}

[1] KRIA, "2009 Statistics on the Radiation Practices in Korea," Korea Radioisotope Association (2010).

[2] MOST, "White Paper on Nuclear Safety," Ministry of Education, Science and Technology (2010).

[3] IAEA, "Building Competence in Radiation Protection and 
the Safe Use of Radiation Sources," Safety Guide No. RSG-1.4, International Atomic Energy Agency, Vienna (2001).

[4 ] IAEA, "International Basic Safety Standards for Protection against Ionizing Radiation and for the Safety of Radiation
Sources," Safety Series No. 115, International Atomic Energy Agency (1996).

[5] IAEA, "Training in Radiation Protection and the Safe Use of Radiation Sources," Safety Reports Series No. 20, International Atomic Energy Agency, Vienna (2001). 